\title{
KAAN Projesi ve Özel Güvenlik Görevlilerinin İş Memnuniyeti Üzerine Bir Araştırma: Ampirik Bir Çalışma
}

\author{
DOI: $10.26466 /$ opus.779809
}

*

\author{
Hakan İnankul * \\ * Doç Dr., Emniyet Genel Müdürlüğü, Özel Güvenlik Denetleme Başkanlığı, Polis Başmüfettişi, \\ 1. Sınıf Emniyet Müdürü, Ankara (Bursa Görev Merkezi) \\ E-Posta: hakaninankul@hotmail.com \\ ORCID: $\underline{0000-0002-0837-8572}$
}

Öz

Güvenliğin ana tedarikçisi ve sahibi Devlettir. Devletler, en önemli işlevlerinden birisi olan güvenlik hizmeti sunumunu polis ve askeri statülü kolluk görevlileri marifetiyle gerçekleştirir. 20. yüzyılın son çeyreğinde dünyada yaşanan sosyal, kültürel ve ekonomik gelişmeler sonrasında devletler, iç güvenlik hizmetlerinin sunumunda paradigma değişikliğine gitmişlerdir. Özellikle sanayileşmiş devletler, bireylerin ve kamuya açılmış özel alanların güvenliğinden büyük oranda çekilerek özel güvenlik olgusunun ve sektörünün ortaya çıkmasının önünü açmışlardır. Türkiye de dünyada yaşanan bu gelişmelerden nasibini almıştır. Sosyal hayatın her alanında karşımıza çıkan genel kolluktan daha görünür olan özel güvenlik görevlilerinin (ÖGG) is memnuniyetlerini anlayabilmek oldukça önemlidir. Çalışmanın amaçlarından birisi ÖGG'lerin iş memnuniyetini ölçebilmek ve güvenlik endüstrisinin doğuşunun sosyal ve ekonomik nedenlerini irdeleyebilmektir. Çalışmanın diğer bir amacı ise Emniyet Genel Müdürlüğ̈̈̈ Özel Güvenlik Denetleme Başkanlı̆̆ınca yürütülen ve ülkenin iç güvenlik toplam kalitesine önemli katkı sağlaması öngörülen Genel Kolluk -Özel Güvenlik Işbirliği ve Entegrasyon (KAAN) Projesi'nin tanttımın yaparak güvenlik mefhumuyla ilgili tüm aktörleri bilgilendirmek ve projenin yaygınlașmasına katkı sağlayabilmektir. Bu amaçlara ulaşabilmek için yöntem olarak literatür taramasının yanında 600 ÖGG üzerinde 2018 yılında nicel araştırma ve inceleme yöntemine dayalı bir anket çalışması yapılmıştır.

Anahtar Kelimeler: Özel Güvenlik Denetleme Başkanlığı, Özel Güvenlik, Güvenlik, Iç̧üvenlik, Özel Güvenlik Görevlisi. 


\title{
A Research on KAAN project and Job Satisfaction of Private Security Officers: An Empirical Study
}

\begin{abstract}
The main supplier and owner of security is the State. States perform security services, one of their most important functions, through the police and law enforcement officers with military status. After the social, cultural and economic developments in the world in the last quarter of the 20th century, states changed their paradigm in the provision of internal security services. In particular, industrialized states paved the way for the emergence of private security phenomenon and sector by withdrawing from the security of individuals and private spaces opened to the public. Turkey also experienced in the world has taken its cue from these developments. It is very important to understand the job satisfaction of private security officers (PSO), who are more visible than the general law enforcement in all areas of social life. One of the aims of the study is to measure the job satisfaction of PSOs and to examine the social and economic reasons for the birth of the security industry. Another aim of the study is to inform all actors related to the concept of security and to contribute to the spread of the project by promoting the General Law Enforcement - Private Security Cooperation and Integration (KAAN) Project, which is carried out by the General Directorate of Security, Directorate of Private Security Inspection and is expected to make a significant contribution to the total quality of the country's internal security. In order to achieve these goals, in addition to the literature review as a method, a questionnaire study based on quantitative research and examination method was conducted on 600 PSOs in 2018.
\end{abstract}

Keywords: Private Security Supervision Department, Private Security, Security, Internal Security, Private Security Officer. 


\section{Giriş}

Devletin en önemli işlevlerinden birisi insanların her türlü tehdit ve tehlikeden uzak bir şekilde emniyet ve asayiş içerisinde yaşamasını sağlamaktır. Devlet bu işlevini iç güvenlik alanında genel kolluk olarak ifade edilen polis, jandarma ve sahil güvenlik teşkilatları marifetiyle yani devletin yürütme aracı olan kamu yönetimi eliyle yürütür.

Farklı sosyal, kültürel ve ekonomik gelişmeler sonrasında devletler iç güvenliğe dair özellikle bireylerin ve kamuya açılmış özel alanların güvenliğinden kısmen çekilerek özel güvenlik olgusunun ve sektörünün ortaya çımasının önünü açmıştır. Bir başka ifadeyle devletler, asli görevi olan güvenlik hizmeti sunumunda -denetiminde ve kontrolünde kalmak şartıyla- kısmen de olsa özel kişilerce görülmesinin hukuki alt yapısını oluşturarak on binlerce insanın çalıştığı, binlerce özel güvenlik şirketinin ve eğitim kurumunun ortaya çıktığı devasa bir güvenlik endüstrisinin doğmasına izin vermişlerdir.

Ülkemizde güvenlik olgusunun sahibi, denetleyicisi, düzenleyicisi ve baş tedarikçisi Devlet'tir. Devlet iç güvenlik hizmetlerini İçişleri Bakanlığına bağlı Emniyet Genel Müdürlüğü (EGM), Jandarma Genel Komutanlığı ve Sahil Güvenlik Komutanlığı eliyle yürütür. Özel güvenlik endüstrisinde yer alan şirketlerin, eğitim kurumlarının ve bu alanda çalışanların çok büyük bir kısmı EGM'nin sorumluluk alanında yer almaktadır.

İçişleri Bakanlığı adına özel güvenlik sektörünü denetleme, düzenleme ve eğitim-sınav faaliyetlerini yürütme görevi EGM Özel Güvenlik Denetleme Başkanlığı (ÖGDB) tarafından ilgili mevzuat çerçevesinde yürütülmektedir. ÖGDB'nin bir diğer amacı da genel kolluğun özel güvenlik ile entegrasyonunu sağlayabilmek, özel güvenlik hizmetlerinin ülkenin iç güvenlik toplam kalitesine daha fazla dahil edilmesi için çaba harcamaktır. Bu amaca ulaşabilmek için Özel Güvenlik Denetleme Başkanlığınca hazırlanarak hayata geçirilen Genel Kolluk - Özel Güvenlik İşbirliği ve Entegrasyon (KAAN) Projesi, öncelikli olarak 25 Mart 2019 tarihinde İstanbul ilinde, akabinde diğer illerde faaliyete geçirilmiştir.

Ülkede sayıları 300 bini aşan özel güvenlik görevlilerinin arama, yakalama, şartlar oluştuğunda silah ve zor kullanma gibi yetkileri vardır. İnsan hak ve özgürlüklerini ve insan yaşamını doğrudan ilgilendiren önemli yetkileri bulunan özel güvenlik görevlilerinin; aldıkları temel ve meslek içi eğitim, 
iş yerinde gördükleri değer ve saygı, iş güvenlikleri, çalışma koşulları, aldıkları ücretin hayatlarını geçindirmek için yeterli olması gibi etmenler yani iş memnuniyetleri oldukça önemlidir. Hiç şüphe yok ki işinden memnun olmayan bir özel güvenlik görevlisinin kaliteli bir güvenlik hizmeti sunması veya iş yerinde ve özel hayatında mutlu olması beklenemez.

Çalışmanın amacı KAAN projesini yaygınlaştırmak, bu yayın yoluyla projenin ulusal ve uluslararası alanda tanıtılmasını sağlamak, özel güvenlik endüstrisinin ortaya çıkışını kabaca irdelemek ve özel güvenlik görevlilerinin iş memnuniyetini ölçebilmektir. Ayrıca (varsa) özel güvenlik görevlilerinin iş memnuniyetini olumsuz yönde etkileyen sorunsallara çözüm önerileri üretebilmektir. Bunun için yöntem olarak yazında öne çıkan bilimsel etkinliklerin incelemesinin yanında ankete dayalı bir alan çalışması yapılmıştır. Özellikle çalışmanın sonuç ve değerlendirme kısmında ortaya konulan bulguların, ülkede hakkında çok az sayıda akademik çalışma yapılan özel güvenlik sektörüne, literatüre ve güvenlik ile ilgili politika yapanlara katkı sağlama potansiyelinden söz etmek mümkündür.

\section{Kavramsal Çerçeve}

Thomas Hobbes, "Güvenlik sağlanmadan insan modern hayattan uzaklaşır, modern hayattan uzaklaşan insan doğal yaşamma döner ve bunun sonucunda yağma ve intikam duygusunu dışa bir türlü yansitır." düşüncesini savunur. Hobbes, eserlerinde insanın çevresine vereceği zararları engellemek için "devlet" denilen otoriteye ihtiyaç olduğuna vurgu yapar. John Locke, Hobbes' in güvenlik anlayışına karşı çıkar. Locke güvenliğin devlet eliyle sağlanamayacağı tezini savunur. Locke güvenliğin sivil toplum örgütleri ve yasama, yürütme ve yargının birbirleriyle tamamen ayrılması sonrasında sağlanabileceği görüşünü ileri sürer. Mill ise esas olanın özgürlükler değil güvenlik olduğunu düşünür. Mill'e göre kanunların esas amacı özgürlükleri korumak değil güvenliği tesis etmektir. Bentham, güvenlik olgusunu diğer sosyal bilimcilerden farklı okur. Bentham'a göre güvenlik bitmeyen bir yolculuktur. Bentham güvenliğin tarifini "beklentilerin emniyeti" olarak yapar (Zedner, 2009, s.35-38).

Güvenlik olgusu, kriminoloji biliminin sınırları içinde düşünülebilecek veya sadece polislik hizmetleri bağlamında ele alınabilecek kadar sığ bir kav- 
ram değildir. Geleneksel anlamda güvenlik; siyaset biliminin, devletler hukukunun ve askeri çalışma alanlarının konusunu oluştururken artık günümüz dünyasında güvenlik fenomeni hemen hemen her disiplini doğrudan veya dolaylı olarak ilgilendiren bir mefhum haline gelmiştir (Zedner, 2009, s.19-21).

Değişen şartlara, tehditlere, toplumsal adetlere ve durumlara göre farklı anlamları bulunan, söylemsel olarak oldukça etkileyici ve güçlü olan güvenlik kavramının (Brauch, 2008, s.2) tek bir tanımından söz etmek mümkün değildir (Montero, 2013, s.205). Çünkü güvenlik fenomeni; insanların gelecek yaşamlarını ilgilendiren sosyal güvenliği, sıhhatli bir şekilde yaşamlarını konu alan sağlık güvenliğini, gecenin bir vaktinde korkusuzca sokaklarda dolaşabilme hissini konu alan sübjektif güvenliği, her türlü dış ülke saldırısından uzak olabilmeyi ifade eden askeri güvenliği, gelecek nesillere daha yaşanabilir bir dünya bırakmaya dair sürdürülebilir bir çevre güvenliğini düşünmek gibi kaygan ve tartışmaya açı bir zeminde bulunur. Çalışmanın konusu kişilerin mallarına, canlarına, ırzlarına ve diğer değerlerine karşı gelebilecek muhtemel tehditlerin yokluğunu, dirlik ve esenliğin hakim olduğu, kamu hizmetlerinin aksamadan yürütüldüğü, genelde kriminoloji bilimini özelde ise polislik uygulamaları içinde yer alan özel güvenlik hizmetlerini ilgilendiren alanla sınırlı olduğundan bu çalışmada güvenlik kavramının farklı disiplinlerdeki kullanımına değinilmeyecektir.

Bunun yanında güvenlik konusu; kamu yönetimi, siyaset, tıp, sosyoloji, çevrebilim, hukuk, ekonomi gibi farklı disiplinlerin çalışma alanına girer. İşte böylesine farkh alanlarda bir arayış içinde olan ve duygusal cazibesi oldukça yüksek olan güvenlik kavramı söylem olarak dikkat uyandırıcı olup tek bir imleme bağlı kalmayacak kadar özgürdür (Zedner, 2009, s. 5-25).

Günümüzde güvenlik olgusu, gerek güvenlik meselesi üzerine kafa yoran araştırmacılar gerekse devletler tarafından daha kapsamlı ve derinlemesine ele alınmaya başlanmışır. Güvenlik kavramını sadece askeri anlamda ele alan gelenekçi yaklaşım artık yerini ulusal sınır güvenliğinin yanında güvenlik olgusunu insan, çevre ve gezegen güvenliğini de içine alan yeni bir güvenlik anlayışına bırakmıştır. Günümüz dünyasında iç ve dış güvenlik ayrımı büyük oranda kalkmıştır (Ağır, 2011, s.103-104; Sancak, 2013, s.125). Güvenliği sadece uluslararası ilişkiler, askeri tehditler, sınırların korunması gibi olgular üzerinden ele almak güvenlik meselesine sığ bir yaklaşım olur. Günümüzde hemen her suç özellikle uyuşturucu, insan kaçakçılığı, terör, siber ve çevreye 
yönelik suçlar artık ülke sınırlarını aşmış bir ülkenin güvenlik meselesi diğer ülkeleri yakından ilgilendirir hale gelmiştir.

Önceleri ulusal çapta görülen terör eylemleri, özellikle 11 Eylül 2001 tarihinde meydana gelen ikiz kulelerden oluşan Dünya Ticaret Merkezine sald1rılar sonrasında uluslararası düzlemde tartışılmaya başlanmıştır (Aşkın, 2019, s.1). Ülkede tehdit oluşturan terör örgütleriyle mücadelede başarılı olmanın yolu PKK, DEAŞ, FETÖ/PDY örneğinde olduğu gibi sını ötesinde de operasyon yapmaktan ve uluslararası işbirliğini artırmaktan geçmektedir. İç güvenlik yönetimini daha etkin yapabilmek için hemen her ülkede o ülkenin polisi kadar sayıya ulaşmış veya bu sayıları aşmış olan özel güvenlik çalışanlarını o ülkenin iç güvenlik toplam kalitesine dâhil etmek oldukça önemlidir.

\section{Özel Güvenlik Endüstrisinin Ortaya Çıkışı}

Özel güvenlik hizmetlerinin bugünkü anlamda tedarik edilmesinin ilk adımları geçen yüzyılın son çeyreğine doğru refah devleti anlayışının yerini neo-liberal akımlara terk etmesiyle atılmıştır. Genelde kamusal hizmetlerin özel yönetimler tarafından sunulması özelde ise güvenlik hizmetlerinin kamuya açılmış özel alanlarda özel güvenlik endüstrisi tarafından verilmesini tetikleyen faktörleri doğru anlayabilmek için sanayileşme dönemi ile klasik liberalizm arasındaki ilişkiyi, refah devletinin sonunu getiren neo-liberal akımları kısaca ele almakta fayda vardır.

19. yüzyıl sonları ve 20. yüzyılın başlarında ortaya çıkan sanayileşme hamleleri toplumların yapısını önemli ölçüde değiştirmiştir. Sanayileşmenin ihtiyaç duyduğu insan emeği, büyük insan gruplarının kırsaldan fabrikaların ve üretim tesislerinin bulunduğu kentlere göç etmesinin zeminini hazırlamıştır. Sanayileşme beraberinde önemli toplumsal sorunları da getirmiştir. Köylerden kentlere yaşanan büyük göçler sonrasında kentlerde oluşan altyapı, barınma, sağlık, eğitim, güvenlik gibi sorunlar sistemin yeniden ele alınması gerektiği sonucunu doğurmuştur. Bahse konu toplumsal çıkmazların yanında ortaya çıkan 1929 ekonomik buhranı (büyük buhran) ve büyük acıların ve kayıpların yaşandığ 12 . Dünya Savaşı sonrasında ortaya çıan tablo liberal düşüncenin sonunu getirmiştir (Eser, Memişoğlu ve Özdamar, 2011, s.202; Durdu, 2009, s.41-42). 
Liberalizm yerini Keynes'in öncülügünü yaptığı devletlerin ekonomide, sağlıkta, eğitimde, güvenlikte, üretimde bizzat rol almasını savunan "refah devleti" anlayışına bırakmıştır. Artık devletler sanayileşme ile ortaya çıkan eşitsizliğin, adaletsizliğin önüne geçmek ve savaş sonrası yaşanan acıları dindirmek için refah devleti anlayışını hayata geçirmeye başlamışlardır. Refah devleti anlayışını uygulamaya koyan özellikle sanayileşmiş devletler insanlara asgari gelir sağlamak, insanları toplumsal tehlike ve tehditlerden korumak, sosyal güvenlik politikalarını uygulamak, herkese eğitim, sağlık hizmeti sunmak ve büyük insan yığınlarının barınma ihtiyacını karşılamak için harekete geçmişlerdir (Durdu, 2009,s. 41-42).

Her bir sistem işlemesi faklı nedenlerden ötürü etkisiz veya imkânsız hale gelinceye kadar sistemi işletenler ve o sistemin nimetlerinden faydalananlar tarafından göklere çıkarılır ve genel bir alkış alır. Ne zaman ki gerek sistemin işleyişinden gerekse diş faktörlerden dolayı sistem işlemez ve sisteme karşı büyük eleştiriler gelirse artık yeni bir sisteme yeni bir yapılanmaya ihtiyaç olduğu dile getirilir. Aslında yeni getirilen sistem geçmişte bir türlü uygulanmış her bir sistemin kendine özgü olan bazı çıkmazlarından dolayı terk edilmiş yani denenmiş bir tecrübeden veya olgudan başka bir şey değildir. İşte klasik liberalizm de on yıllar sonra bir döneme kendini unutturduktan sonra önüne sadece "neo" ibaresini koyarak "neo-liberalizm" adı altında 1970'li yılların sonunda tekrar devletlerin gündemine gelmiştir.

1970'li yılların başlarında yaşanan petrol krizi, devletlerin hayatın her alanına el atarak büyük bütçe açıkları vermesi, kamu borçlanmalarının yönetilemez hale gelmesi, kamu hizmetlerinin çok pahalıya mal olması ve verimsizleşmesi gibi nedenler devletlerin refah devleti anlayışını yeniden masaya yatırmasına neden olmuştur. Özellikle "Yeni Sağ" olarak isimlendirilen partiler ve bunların başlarında bulunan liderler (İngiltere' de Margaret Thatcher, ABD' de Ronald Reagan) devletin yapı ve işlevinde radikal değişimlere gitmişler ve devletin sosyal ekonomik hayatın her alanına doğrudan müdahalesini kısıtlayan önemli reformlar yapmışlardır. 1980'li yılların başından itibaren neo-liberal akımın savunucuları, her alanda çeşitli hizmetler üreten devletin daha az devlet, daha çok piyasa anlayışı doğrultusunda özelleştirme ve deregülasyon politikalarına gitmesinin zorunlu olduğu yönündeki politikaları savunmuşlardır (Eryılmaz, 2016, s.49-50). 
Türkiye de dünyada yaşanan neo-liberal akımların etkisiyle 1984' de kabul edilen 2983 sayılı kanun ile özelleştirme faaliyetlerine başlamıştır. Özal hükümetiyle başlayan özelleştirme çabalarının amacı Kamu İktisadi Teşebbüslerinin (KİT) zararlarını kapatmak, devletin sunduğu kamusal hizmetlerin etkinliğini ve verimliliğini artırmaktı.

Bugünkü anlamda sunulan özel güvenlik hizmetlerinin ülkemizde ve dünyada ortaya çııısı neo-liberal akımların bir ürünüdür. Devletler, asli görevi olan güvenlik hizmeti sunumunda (denetiminde ve düzenlenmesinde kalmak şartiyla) kısmen de olsa özel kişilerce görülmesinin hukuki alt yapısını oluşturarak yüzbinlerce insanın çalıştı̆̆ı, binlerce özel güvenlik şirketinin ve eğitim kurumunun ortaya çıtığ 1 devasa bir güvenlik endüstrisinin doğmasına izin vermişlerdir. Bu durum tıpkı devletin asli görevlerinden olan eğitim ve sağlık gibi bazı kamusal hizmetlerin denetiminde ve düzenleyiciliğinde kalması şartıyla özel yönetimlerce (özel okullar, özel hastaneler vb.) verilmesinin önünü açması gibidir.

\section{KAAN Projesinin Tanıtımı ve Projenin Ülkenin İç Güvenlik Toplam Kalitesine Etkisinin Kısa Değerlendirilmesi}

Yeni kamu yönetimi (YKY) anlayışını geleneksel yönetimden ayıran en önemli özellik, YKY'nin devlet kaynaklarının daha verimli ve daha etkin kullanmasını temel yönetim ilkesi olarak kabul etmesidir (Boztepe, 2018, s.192193). Devlet yeni yönetim anlayışı doğrultusunda iç güvenliği gerektiği gibi sağlayabilmek için elinde bulunan insan, araç-gereç ve mali kaynakları etkin ve verimli kullanmak zorundadır. Çünkü güvenlik hizmeti sunmanın devlete hatırı sayılır bir ekonomik maliyeti vardır.

Her bir devlet suçu engellemek (proaktif) ve suçlularla daha etkin mücadele etmek için (reaktif), genel kolluğun kabiliyetinin yanında özel güvenlik sektörünün sahip olduğu maddi ve beşeri kaynakları toplam iç güvenlik kalitesine maksimum derecede dahil etmek ister. İşte bu anlamda KAAN projesi önemlidir. Çünkü KAAN projesi; güvenlik eğitimi almış, çevresindeki gelişmelere güvenlikçi gözüyle bakabilen, hayatın her alanına dağılmış (AVM, metro istasyonları, terminaller, havalimanları, hastaneler, okullar, parklar, müzeler vb.) ve güvenlik cihaz ve teknolojilerini kullanabilen üç yüz bin özel güvenlik personelini suçu engellemede ve suçla mücadelede daha etkin ve 
verimli kullanmayı hedeflemektedir. Özel güvenlik sektörünün iç güvenlik hizmetlerine daha fazla dahil edilmesinin devlete hiçbir maliyeti bulunmamaktadır.

Proje kapsamında genel kolluk ile özel güvenlik arasında etkili iletişim araçları kullanılmaktadır. ÖGG'ler bir suç veya suç şüphesiyle karşılaştıklarında daha önceden tanımlanmış iletişim araçlarıyla genel kolluğu anında bilgilendirmektedir. KAAN bildirimi olarak isimlendirilen behse konu anlık bilgi akışı sayesinde genel kolluk dakikalar içinde -muhtemel- olay(lar)a müdahele edebilmektedir. Her bir KAAN bildirimi il emniyet müdürlüklerince kayıtlara geçirilmektedir. Suçlara göre tasnifi yapılmış ve detaylandırılmış bu kayıtlar sayesinde ilerleyen zamanda bu projesinin iç güvenlik yönetimine katkısı istatiktisel olarak ortaya konulabilecektir.

KAAN projesinin hedeflerine ulaşabilmek için tüm ÖGG çalışanlarına planlanan ve denetlenen bir süreçte formal eğitim (İnal, 2014, s.183) yöntemiyle özel güvenlik hukuku, genel kolluk-özel kolluk ilişkileri ve projenin metodolojisini ve önemini anlatan seminerler düzenlenmektedir. Projenin kısa tan1tımına dair bilgilendirme metni ilgili web sayfasından alınarak aşağıda sunulmuştur.

Genel Kolluk - Özel Güvenlik İşbirliği ve Entegrasyon (KAAN) Projesi, öncelikli olarak 25 Mart 2019 tarihinde İstanbul ilinde ve akabinde diğer illerimizde faaliyete geçirilmiştir. "Türkiye benim ülkem, Türkiye için ben de hazırım" sloganı ile KAAN uygulamasında; kamu güvenliğini tamamlayıc mahiyette görev yapan özel güvenlik görevlilerinin, görev yaptıkları kamu hastaneleri, eğitim kurumları, havalimanları, alı̧veriş merkezleri, park ve bahçeler ile toplu taşıma istasyonlarn ve güzergâhlarn ile diğer uygun görülen yerlerde;

- Amacina uygun, etkin, verimli, denetlenebilir, sürdürülebilir ve ölçülebilir güvenlik hizmetinin sunulmasl,

- Özel güvenlik görevlilerinin aidiyet duygularının geliştirilmesi,

- Özel güvenlik ve genel kolluk görevlilerinin etkin işbirliği ve koordinasyonu ile olay meydana gelmeden suçun önlenmesi,

- Meydana gelen olaylarda ise en seri şekilde genel kolluğa bildirilmesi amaçlanmıştır.

Özel güvenlik genel kolluk işbirliği ve entegrasyonu KAAN projesi kapsamında; Özel Güvenlik Hukuku, Genel Kolluk ile Özel güvenlik İlişkileri, Genel Kollukla İşbirliği ve Koordinasyon, Etkili İletişim, Görev Yeri Güvenlik Farkındalı̆̆ ve Kaan uygulaması konularmda uygulama kapsamında görev yapacak genel kolluk ve özel güvenlik görevlilerine eğitimler verilmiştir (EGM, 01.08.2020). 


\section{Özel Güvenliğin Amacı}

Özalp, özel güvenlik hizmetlerini "ticari faaliyetleri destekleyen ve bu faaliyetleri kolaylaştıran yardımo bir işletme fonksiyonu" olarak tarif eder (Özalp, 2016: s.1). 5188 sayılı Özel Güvenlik Hizmetlerine Dair Kanun ise özel güvenlik hizmetlerini kamu güvenliğini tamamlayıcı mahiyette ele alır. 5188 sayılı kanun özel güvenlik sektörünün işletme fonksiyonuna vurgu yapmaz.

Devletin sunduğu güvenlik hizmetleriyle özel güvenlik endüstrisinin sunduğu güvenlik hizmeti ve emtiası arasında amaca dair önemli farklılıklar vardır. Kamusal düzeni korumak, ülkedeki suç oranlarını azaltmak, genel asayişi sağlamak, suçluları yakalamak gibi genel kolluğun temel görevleri özel güvenliğin yönetim paradigması içinde fazlaca yer almaz. Özel güvenliğin temel meselesi müşteri memnuniyetini sağlamaktır. Bazen çalıştığı yerin marka değeri zarar görmesin diye -kanunen zorunlu olmasına rağmen- karşılaştığı bazı suçları genel kolluğa bildirmek istemeyebilir. Doğru olan, özel güvenlik olgusunun, bir işletme fonksiyonu olarak işletmenin çkarlarını düşünürken, ülkenin iç güvenlik toplam kalitesine katkı yapmayı ve iş ve işlemlerinde hukukun içinde kalmayı genel yönetim paradigması olarak göz önünde bulundurmasıdır. KAAN projesinin bir amacı bu yönetim paradigmasını gerçekleştirebilmektir.

Türkiye'de özel güvenlik birimleri sadece ülke içinde farklı kurum ve kuruluşlarda güvenlik hizmeti sunmaktadırlar. Fakat günümüz dünyasında bir çok ülkede özel güvenlik hizmetleri ülke sınırlarını aşmıştır. Bazı özel güvenlik şirketleri ulasal sınırlarını aşarak farklı ülkelerde silahlı ve silahsız olarak polislik ve askerlik hizmetleri adı altında güvenlik hizmeti sunmaktadır. Birleşmiş Milletler (UN) Barış Gücünün bulunduğu bazı ülkelerde, EUPOL, EULEX gibi uluslararası örgütlerin merkez yönetim binalarının güvenliğinin alınmasında özel güvenlik görevlilerini görmek mümkündür (Krahmann ve Friesendorf, 2011, s.5-6).

\section{Özel Güvenlik Görevlilerinin İş Memnuniyetine Yönelik Bir Araştırma}

\section{Araştırmanın Amacı}

Araştırmanın amacı özel güvenlik görevlilerinin iş memnuniyetini ölçebilmek ve (varsa) özel güvenlik çalışanlarının iş memnuniyetini olumsuz yönde etkileyen faktörleri çözüm önerileriyle birlikte ortaya koyabilmektir. 


\section{Araştırmanın Evreni ve Örneklemi}

Araştırmanın evreni Türkiye'de kamuda ve özel sektörde çalışan tüm özel güvenlik görevlileridir. Çalışmanın örneklemi Bursa ilinde özel ve kamu sektörünün farklı birimlerinde görev yapan 600 ÖGG'dir. Örneklemi oluşturan 600 ÖGG, Bursa ilinde 2008 yılının Nisan ayında bir gün süren “Özel Güvenlik Hizmetlerini İyileştirme ve Geliştirme Semineri”ne katılan yaklaşık 2500 ÖGG içinden rassal yöntemle belirlenmiştir. Seminer sonrasında hazırlanan anket formları semineri sunan araştırmacı tarafından 600 ÖGG'ye dağıtılmış ve yaklaşık 20 dakika sonra doldurulmuş formlar analiz yapılmak üzere araştırmacı tarafından toplanmıştır.

Örneklem hacimlerinin belirlenmesinde farklı yöntemler bulunmaktadır. Bunlardan birisi de hazırlanmış tablolardır. Türkiye' de yaklaşık 300.000 ÖGG bulunmaktadır. Araştırmaya katılan 600 ÖGG'nin çalışmanın genel evrenini oluşturan 300.000 ÖGG'yi temsil ettiğini (anakütle büyüklügüne göre örneklem büyüklüğünün uygun olduğunu -( \pm \%5)- Aytaç ve Serper tarafından ortaya konulan tabloya göre ifade etmek mümkündür (Aytaç ve Serper, 2000, s.27).

\section{Araştırma Yöntemi}

Araştırmada yöntem olarak anket soru maddelerine dayalı nicel araştırma yöntemi kullanılmıştır. Ankette yer alan ölçek soru maddelerinin oluşturulmasında daha önce yazında sıklıkla kullanılan özel teşebbüslerde ve kamuda çalışanların iş memnuniyetini ölçmeye yarayan soru maddeleri özel güvenlik sektörüne uyarlanmaya çalışılmıştır. Bunun yanında ölçek soru maddelerinin hazırlanmasında, yaklaşık 30 yıldır güvenlik hizmetlerinde görev yapan, son altı yıldır özel güvenlik sektörünün denetlenmesinde ve çalışanlarının eğitiminde bizzat bulunan bu çalışmayı yapan araştırmacının mesleki tecrübesi ve akademik birikimi de etkili olmuştur. Anket soru maddelerinin güvenilirlik test analizi 0,882 çıkmıştır.

\section{Araştırmanın Bulguları ve Analizi}

Anket soru maddelerinin her biri tablolar haline dönüştürülmüştür. Sonrasinda deneklerin demografik yapısına göre ayrı tablolar şeklinde sayısal ve yüzdelik oranlarla istatistiki bilgi haline getirilmiştir. 


\section{Ankete Katılanların Demografik Yapısı}

> Ankete katılan 600 ÖGG'nin \%4'ü 18-25, \%31'i 26-35, \%42'si 34-41, \%22'si ise 42 ve üstü yaş aralığındadır. Çalışanların \%77'sinin 18-41 yaş aralığında olması bu mesleği yapanların büyük çoğunluğunun genç ve orta yaş çalışanlardan oluştuğunu göstermektedir.

$>$ Araştırmaya katılanların \%17'si kadın, \%83'ü ise erkektir.

> Ankete katılanların \%13'ü ilk öğretim, \%72'si lise, \%14'ü ise üniversite mezunudur.

> Ankete katılanların \%83'ü evli, \%17'si ise bekârdır.

\section{Ankete Katılanlara Sunulan Sosyal İmkânlar}

> Ankete katılanların \%62'si işyerlerinde kendilerine yemek, çay gibi imkânların sağlandığını, \%38'i ise sağlanmadığını ifade etmişlerdir.

> Ankete katılanların \%86'sı işe gidiş-geliş masraflarının karşılandığını, \%14'ü ise karşılanmadığını ifade etmiştir.

> Ankete katılanların \%77'si kendilerine verilen pantolon, kazak, mont gibi üniforma ihtiyaçlarının sayı ve kalite itibariyle yeterli olduğunu, \%23’ü ise yeterli olmadığını ifade etmiştir.

> Ankete katılanların \%37'si kamu \%63'ü ise özel teşebbüs çalışanıdır.

\section{Ankete Katılanların İş Memnuniyeti Algısı}

Anketin bu bölümünde aşağıda olduğu gibi 3’lü likert ölçeği kullanılmıştır.

1-Katıliyorum

2-Kısmen/Bazen Katiliyorum

3-Katılmiyorum

\section{$56 ; 9 \%$}

$143 ; 24 \%$

\section{$401 ; 67 \%$}

Tablo 1. Mesleğe giriş öncesi aldı̆̆ım özel güvenlik temel eğitiminin işim için yeterli olduğunu düşünüyorum. 
Ankete katılan 600 ÖGG'nin 401'i mesleğe giriş öncesi aldığı özel güvenlik temel eğitiminin yeterli olduğunu, 143'ü kısmen yeterli olduğunu, 56'sı ise yetersiz olduğunu ifade etmiştir.

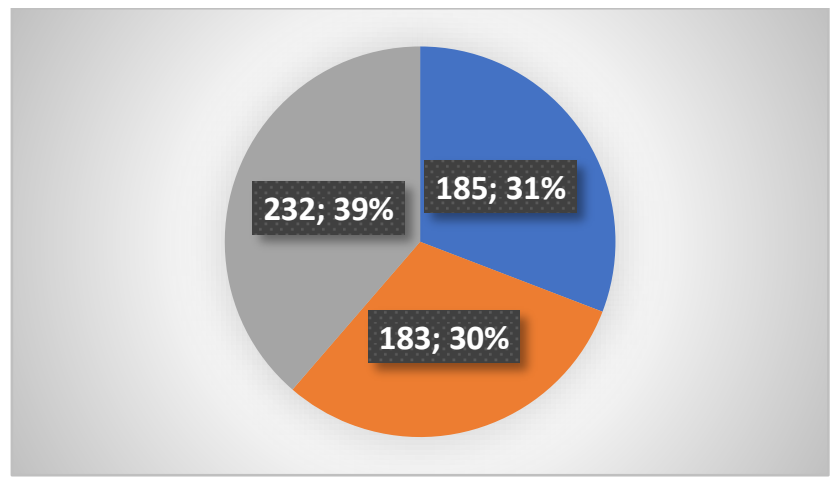

Tablo 2. Çalışma ortamım ve çalışma koşullarm ile ilgili yapılacak düzenlemelerde görüşüme başvurulur.

Ankete katılan 600 ÖGG'nin 232'si çalışma ortamı ve çalışma koşulları ile ilgili yapılacak düzenlemelerde görüşlerine başvurulduğunu, 183'ü görüşlerine kısmen başvurulduğunu, 185'i ise görüşlerine başvurulmadığını ifade etmiştir.

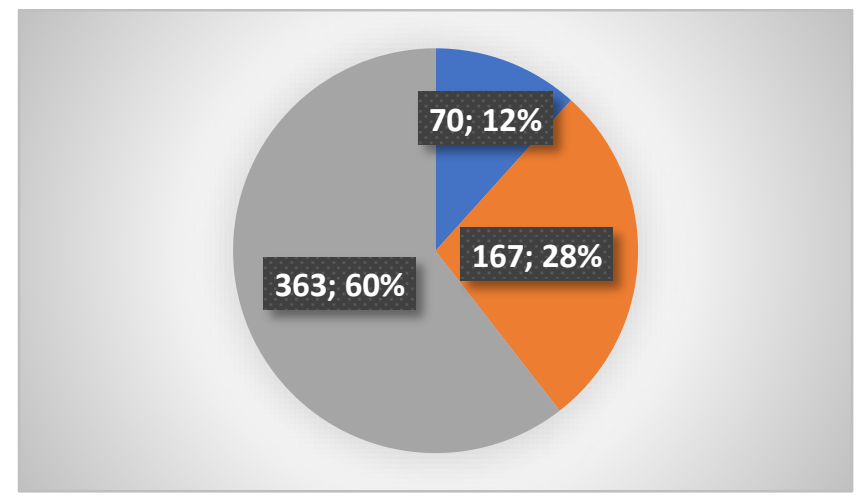

Tablo 3. Çalışma mekânım insani koşulları taşımaktadır

Ankete katılan 600 ÖGG'nin 363'ü çalışma mekânlarının insani koşulları taşıdığını, 167'si insani koşulları kısmen taşıdığını, 70'i ise çalışma mekânlarının insani koşulları taşımadığını ifade etmiştir. 


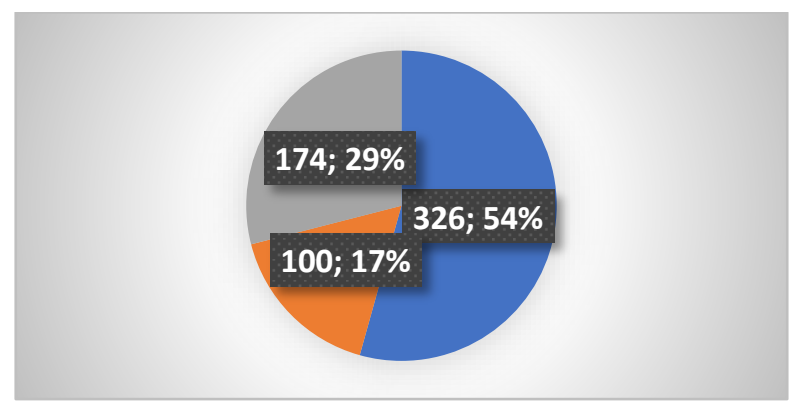

Tablo 4. Çalıştığım bölïmde kariyer yapma (yükselme) imkânım vardır.

Ankete katılan 600 ÖGG'nin 174'ü çalıştığı bölümde kariyer yapma (yükselme) imkânlarının bulunduğunu, 100'ü kariyer imkânlarının kısmen olduğunu, 326'sı ise çalıştıkları kurumda kariyer yapma (yükselme) imkânlarının bulunmadığı ifade etmiştir.

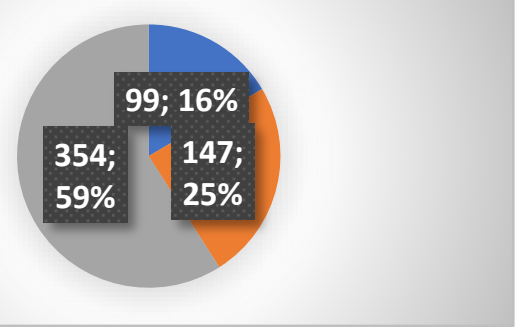

Tablo 5. Zaruri hallerde işyerinden kolaylıkla izin alabilmekteyim.

Ankete katılan 600 ÖGG'nin 354'ü zaruri hallerde işyerinden kolaylıkla izin alabildiğini, $147^{\prime}$ si kısmen izin alabildiğini, 99'u ise zaruri hallerde işyerinden izin alamadığını ifade etmiştir.

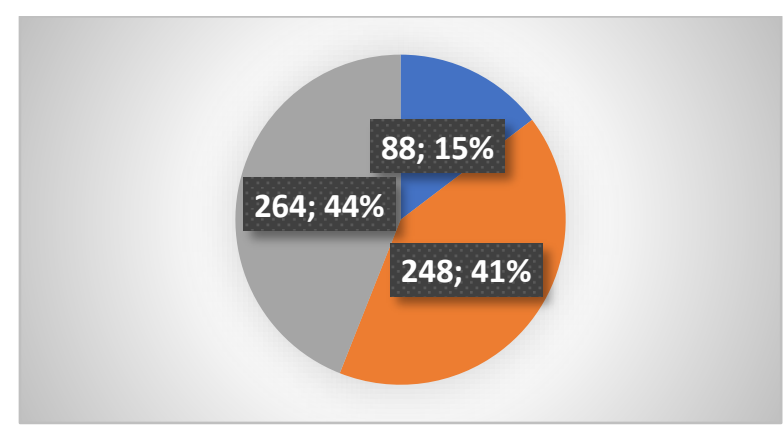

Tablo 6. Taşıdığım üniformama saygı duyulmaktadır. 
Ankete katılan 600 ÖGG'nin 264'ü taşıdığı üniformasına saygı duyulduğunu, 248'i taşıdığı üniformasına kısmen/bazen saygı duyulduğunu, 88'i ise taşıdığı üniformaya saygı duyulmadığını ifade etmiştir.

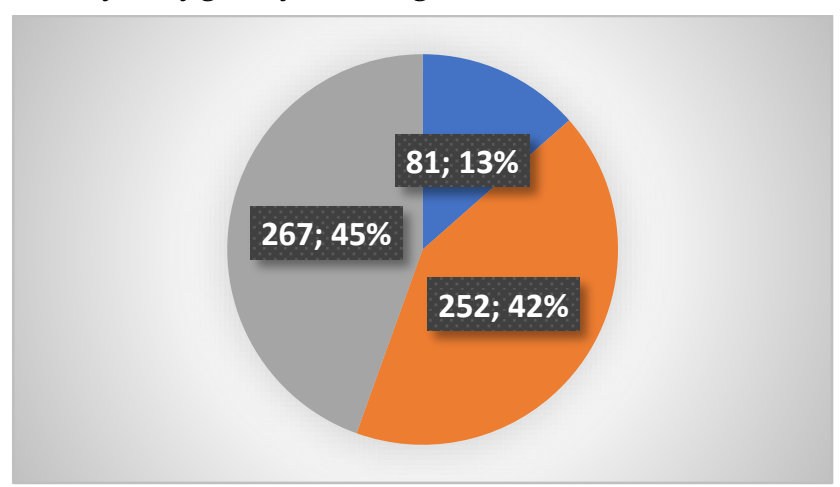

Tablo 7. Sağlanan teknik ve teknolojik güvenlik cihazlarn işimi yapmam için yeterlidir.

Çalışmaya katılan 600 ÖGG'nin 267'si sağlanan teknik ve teknolojik güvenlik cihazlarının işlerini yapmaları için yeterli olduğunu, 252'si kısmen yeterli olduğunu, 81 'i ise kendilerine sağlanan teknik ve teknolojik imkânların işlerini yapmak için yetersiz olduğunu ifade etmiştir.

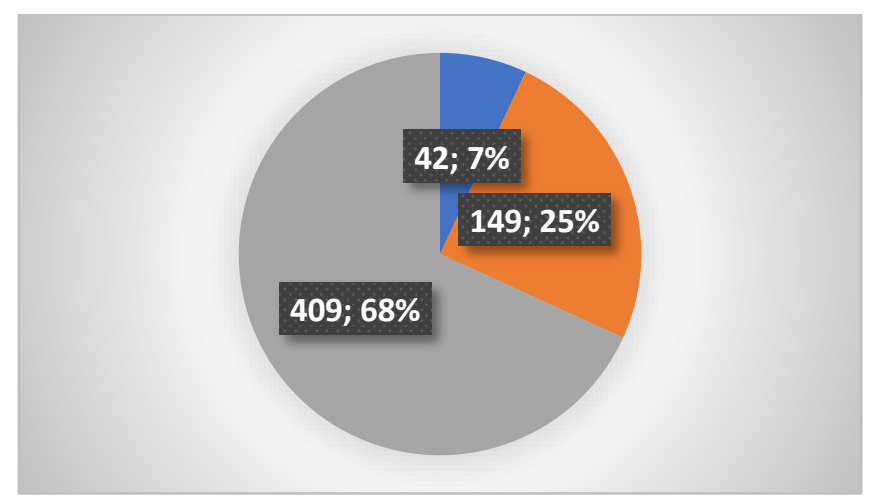

Tablo 8. Yöneticilerime sorunlarımı iletme imkânım vardır.

Ankete katılan 600 ÖGG'nin 409'u yöneticilerine sorunlarını iletme imkânlarının olduğunu, 149'u böyle imkânlara kısmen sahip olduklarını, 42'si ise muhtemel sorunlarını yöneticilerine iletme imkânlarının olmadığını ifade etmiştir. 


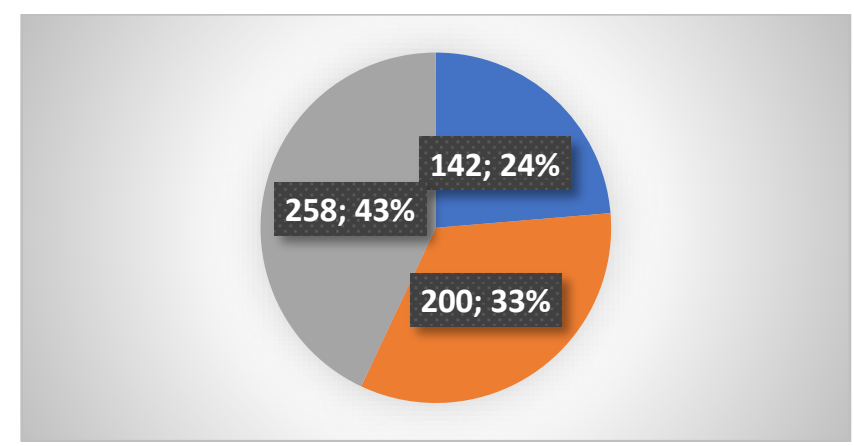

Tablo 9. Aldığım ücretten memnunum.

Anket çalışmasına katılan 600 ÖGG'nin 258'i aldıkları ücretten memnun olduklarını, 200'ü kısmen memnun olduklarını, 142'si ise aldıkları ücretten memnun olmadıklarını ifade etmiştir.

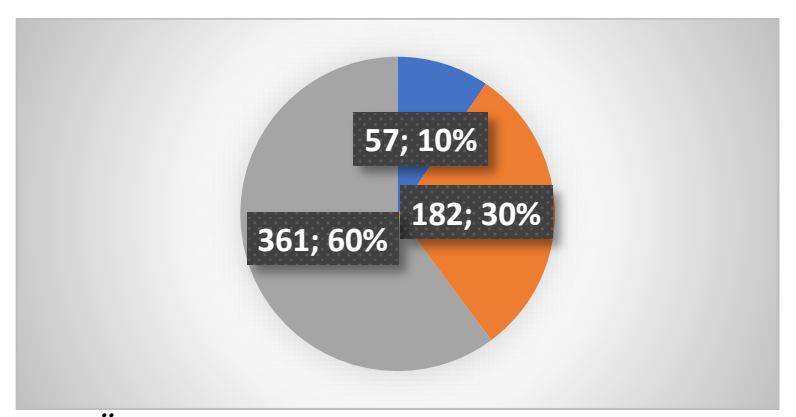

Tablo 10. Özel güvenlik görevlisi olarak çalışmaktan memnunum.

Ankete katılan 600 ÖGG'nin 361'i özel güvenlik görevlisi olarak çalışmaktan memnun olduğunu, 182'si kısmen memnun olduğunu, 57'si ise özel güvenlik görevlisi olarak çalışmaktan memnun olmadığını ifade etmiştir.

\section{Araştırma Bulgularının Analizi}

\section{Araştırmanın Öne Çıkan-Çarpıcı Sonuçları}

Çalışmanın bu ve sonraki kısmında ölçek soru maddelerine verilen cevaplar aşağıda olduğu gibi üç cevaptan oluşmaktadır.
1-Hayır
2-Kismen/Bazen
3-Evet 
Aşağıda yapılan analizde yüzdelik oranlar verilirken evet (3) ve kısmen/bazen (2) cevaplarının toplamı olumlu olarak değerlendirilmiştir.

Tablo 11. “Özel güvenlik görevlisi olarak çalışmaktan memnunum” önermesine verilen cevaplarn ÖGG'lerin cinsiyetine göre analizi:

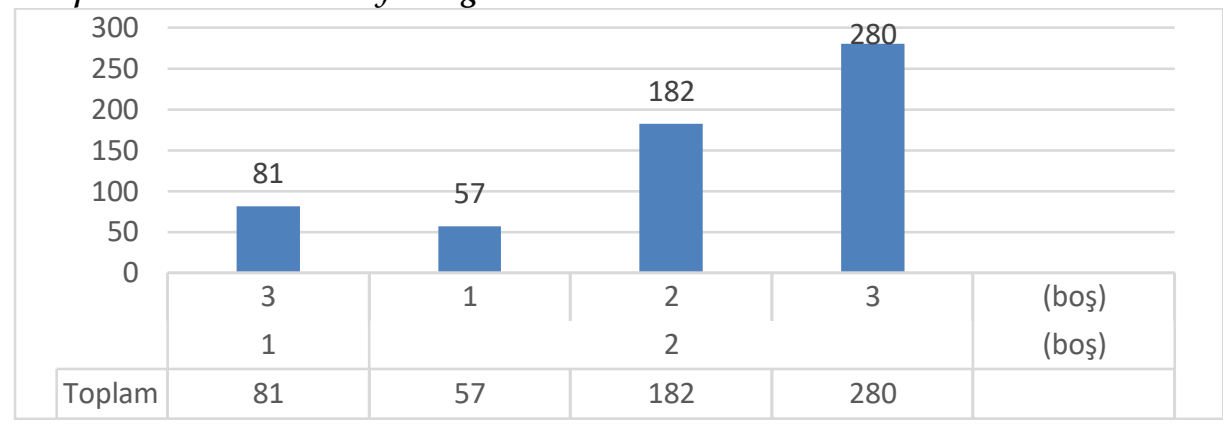

600 deneğin 81'i kadın, 519'u ise erkektir. Kadınların tamamı ÖGG olarak çalışmaktan memnun olduklarını ifade etmişlerdir. Bu çarpıcı sonucun nedenlerini şöyle açklamak mümkündür: Ülkede kadınların iş bulma konusunda erkeklere göre daha dezavantajlı durumda olmaları, kadınların nokta görevlerinde erkekler kadar sabırsız olmaması, hizmeti alanların kadınlara daha kibar davranmaları, kadınların aldıkları ücret ile ailelerine ikinci bir gelir olarak ekonomik katkı sağlamaları ve bu nedenle ödenen ücreti yeterli bulmalarıdır. Bu çarpıcı sonucun daha fazla araştırılmaya muhtaç olduğu düşünülmektedir.

Tablo 12. Kamu görevlisi olan ve kamu görevlisi olmayan ÖGG'lerin “Özel güvenlik görevlisi olarak çalışmaktan memnunum" önermesine verdikleri cevaplarn analizi:

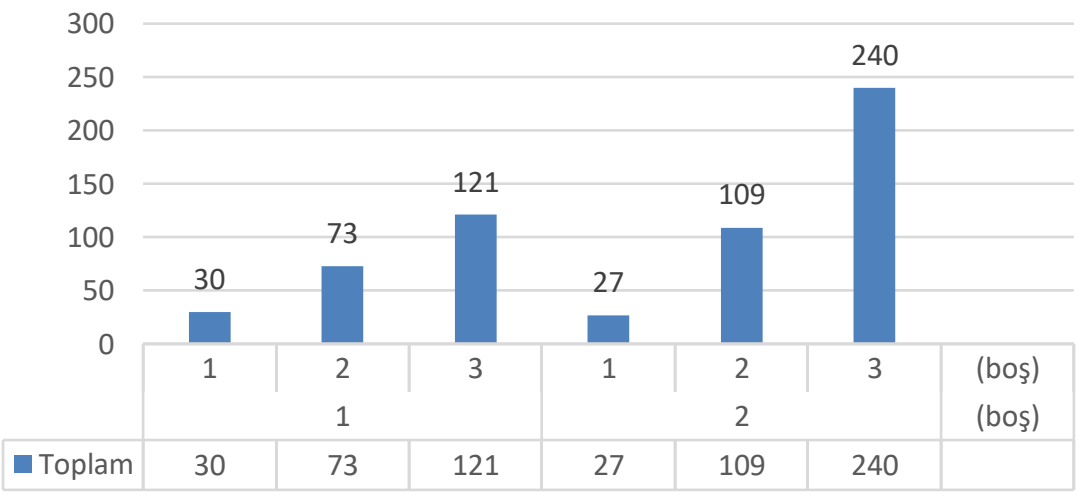


Bu çalışmanın bulgularına ulaşılmadan önce kamuda çalışan ÖGG'lerin özel teşebbüslerde çalışan ÖGG'lere göre işlerinden daha memnun olduğu düşünülmekteydi. Böyle yaygın bir düşünceye sahip olmanın nedeni ise kamu personeli olarak çalışan ÖGG'lerin iş güvencelerinin bulunması, ücretlerinin özel teşebbüste çalışan meslektaşlarından daha yüksek olması, çalışma koşullarının ve sosyal haklarının daha iyi olması gibi gerekçelerdi. Oysaki anket sonuçları durumun hiç de öyle olmadığını göstermiştir. Deneklerin 376'sı özel 194'ü ise kamu personelidir. Kamu görevlisi olarak istihdam edilen ve ücretleri, özlük hakları, çalışma koşulları özel teşebbüslerde çalışan meslektaşlarına göre daha iyi durumda bulunan ÖGG'lerin yüzde \% 15 'i işinden hiç memnun değilken \%85'i ise kısmen veya tamamen memnundur. Özel teşebbüste çalışan ÖGG'lerin ise sadece \%7'si işinden memnun olmad1ğını, \%93'ü ise kısmen veya tamamen memnun olduğunu ifade etmiştir.

Tablo 13. Kamu görevlisi veya özel teşebbüs çalışanı olanlarn "aldiğım ücretten memnunum" önermesine verdikleri cevaplarn analizi:

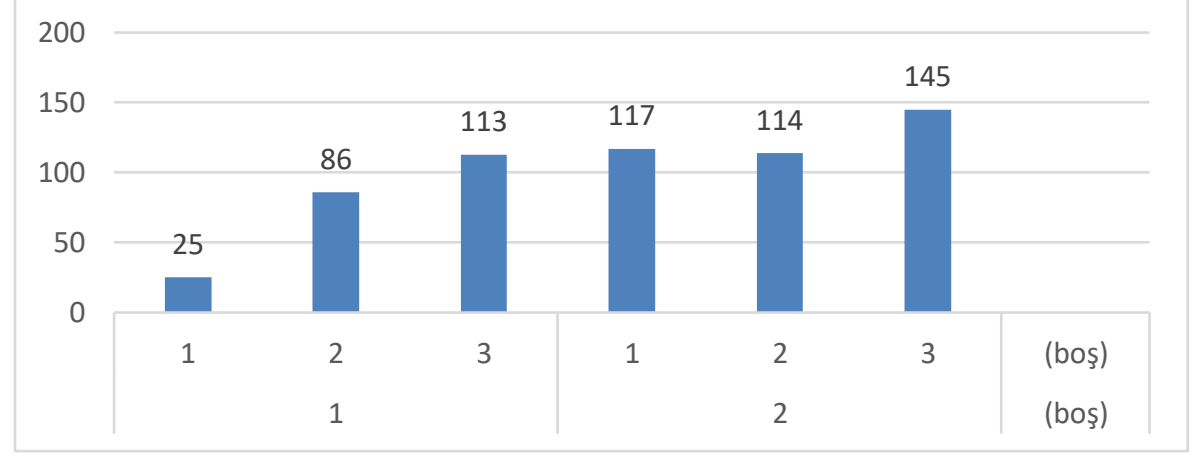

600 ÖGG'nin 224'ü kamu personeli, 376'ı ise özel teşebbüs çalışanıdır. Kamu personeli olan 224 ÖGG'nin 199'u (\%89) aldığ1 ücretten memnundur. Özel teşebbüs çalışanı olan 376 ÖGG'nin 259'u (\%68) aldığı ücretten memnundur. Kamu görevlisi olan ÖGG'lerin aldığ ücretlerin özel teşebbüste çalişan meslektaşlarından daha yüksek olduğu bilinen bir gerçektir. Bir önceki tablonun analizi de dikkate alındığında "özel güvenlik endüstrisinde alınan ücretin fazlalığı iş memnuniyetini yükseltmek için tek başına önemli bir parametre değildir" şeklinde bir sonuca ulaşmak mümkündür. 
Tablo 14. Medeni duruma göre "özel güvenlik görevlisi olarak çalışmaktan memnunum" önermesine verilen cevaplarn analizi:

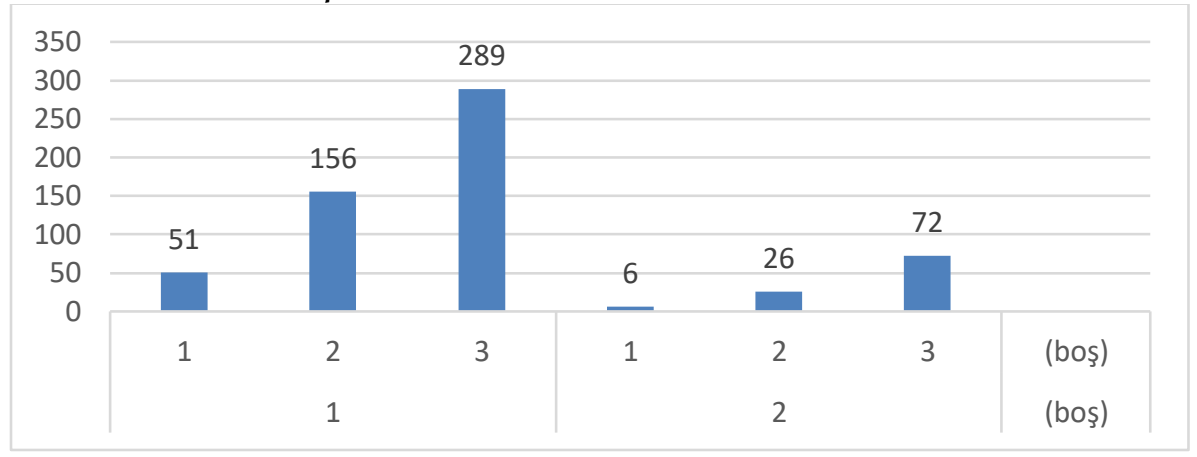

600 ÖGG'nin 496'sı evli 104'ü ise bekârdır. 496 evli ÖGG'nin \%10'u ÖGG olarak çalışmaktan memnun değildir. 104 bekâr ÖGG'nin ise \%5'i ÖGG olarak çalışmaktan memnun değildir. ÖGG olarak çalışmaktan memnuniyetin medeni duruma göre iki kat oranında değişmesinin nedenini ÖGG'lerin vardiya sistemine göre çalışmasına bağlamak mümkündür. Nitekim bir gün gece bir gün gündüz veya 12-24, 8-24, 12-36, 12-12 gibi vardiyalı sistemlerde çalışanların ailelerine vakit ayıramadığı, aileleri uyurken kendilerinin görevde olduğu, kendileri uyurken aile fertlerinin okulda, işte yani gündüz şartlarını yaşadığı bilinmektedir. Bu durum evli ÖGG'lerin iş memnuniyetini etkilemektedir.

\section{Bulgularn Kisa Analizi}

Araştırmacı gerek özel güvenlik sektörünün denetimlerinde gerek ise vermiş olduğu seminerlerde özel güvenlik görevlilerinin çalışma şartlarına, özlük haklarına, iş yüküne vb. dair yakınmalar duymuştur. Fakat yapılan bu saha çalışması sonrasında ÖGG'lerin iş memnuniyetlerinin beklenenden daha yüksek olduğu ortaya çıkmıştır. Çalışmaya katılan ÖGG'lerin \%90'ı ÖGG olarak çalıs̆maktan memnun/kısmen memnun olduğunu ifade etmiştir. Özellikle bayanların hepsinin ÖGG olarak çalışmaktan memnun olması çalışmanın çarpıcı sonuçlarından biridir. 


\section{Sonuç ve Değerlendirme}

Bu çalışmayı yapan araştırmacı polis yaklaşık son 6 yıldır Emniyet Genel Müdürlüğü Özel Güvenlik Denetleme Başkanlığında görev yapmaktadır. Araştırmacı, bu son 6 sene içinde farklı kentlerde bulunan binlerce özel güvenlik görevlisini, yüzlerce özel güvenlik şirketini-eğitim kurumunu denetlemiş ve yine özel güvenliğe dair eğitim seminerlerine konuşmacı olarak katılmıştır.

Araştırmacı, bir kamu görevlisi olarak kendisine verilen işi yaparken aynı zamanda bu devasa sektörde çalışan ÖGG'lerin iş psikolojilerini, işe bakışlarını, çalışma şartlarını, özlük haklarını, işlerini severek yapıp yapmadıklarını yani iş memnuniyetlerini anlamaya çalışmıştır. Ayrıca bu endüstrinin ülkenin iç güvenliğine katkı să̆lama potansiyelini araştırmıştır. Araştırmacı bu ve benzeri sorulara cevap ararken Türkçe ve yabanc yazında özel güvenlik olgusuna dair bilimsel çalışmaları incelemiştir. Araştırmacı, ülkede özel güvenlik görevlilerinin iş memnuniyetini ortaya koyan ve özel güvenlik görevlilerinin ülkenin iç güvenlik yönetimine katkısını konu alan detayl-güncel bir çalışmaya rastlamamıştır.

KAAN projesi, özel güvenlik çalışanlarını ülkenin iç güvenlik toplam kalitesine daha fazla katmayı hedefleyerek güvenlik hizmeti sunumunda yeni bir iç güvenlik paradigması ortaya koymuştur. Projenin, -devlete hiçbir maliyet yüklemeden- iç güvenlik hizmetlerine önemli oranda katkı sağlama potansiyeli vardır.

KAAN projesini diğer ülkelerin -politika transferi yöntemiyle- kendi yönetimlerine uyarlayarak hayata geçirmeleri mümkündür. Bu makaleyi hazırlayan araştırmacı, projenin daha kapsamlı anlatıldığı İngilizce bir makaleyi uluslararası alanda tanınmış bir hakemli dergide yayınlatarak projenin uluslararası alanda duyulmasına ve yaygınlaştırılmasına katkı sağlamayı planlamaktadır.

Ülkenin iç güvenlik yönetimine önemli katkı sağlayan özel güvenlik sektörünün iyileştirilmesi ve geliştirilmesine dair aşağıda yazılı yönetsel ve hukuki düzenlemelerin yapılmasının alana katkı sağlayacağı değerlendirilmektedir:

> Özel Güvenlik Programlarının bulunduğu üniversitelerin Web sayfalarına bakıldığında her bir üniversitenin kendi derslerini koyduğu/okuttuğu görülmektedir. Özel güvenlik programlarının bulunduğu üniversitelerin Polis Akademisi Başkanlığı, Jandarma ve Sahil Güvenlik Akade- 
misi ve Özel Güvenlik Denetleme Başkanlığı ile birlikte çalışarak derslerin ve içeriklerinin belirlenmesi gerekir. Her bir üniversitenin özel güvenlik programında müfredatı aynı olan dersler verilmelidir. Ayrıca özel güvenlik programlarında ders veren öğretim üyelerinin ve görevlilerinin güvenlik bilimi alanında çalışmaları olan ve eğer mümkün ise sahadan gelmiş eğitmenlerden oluşması gerekir. Kişiye uygun ders hazırlamak yerine özel güvenlik sektörünün gerçeğine uygun dersler hazırlanmalıdır ve bu dersler uzmanları tarafindan verilmelidir.

> Özel güvenlik çalışanları tüm dünyada olduğu gibi çalıştıkları alana göre uzmanlaşmalıdır. Bazı özel güvenlik hizmetleri için ilgili alanda uzmanlaşma eğitimi alma zorunluluğ $u$ yeni bir düzenleme ile getirilmelidir. Özel güvenlik eğitim kurumlarının yakın koruma, stratejik bina ve tesisleri koruma, havalimanı güvenliği, para ve değerli eşya nakli gibi konularda uzmanlık eğitimi verebilme kapasitelerine sahip olmalıdır.

> En az bir sivil üniversitede Güvenlik Bilimleri Fakültesi açılmalıdır. Bu fakülte, üniversitelerin "Mülkiyet Koruma ve Güvenlik Programı" mezunlarına lisans tamamlayabilme firsatı vermelidir. Ayrıca polisler, askerler ve güvenlik alanında uzmanlaşmak isteyen araştırmacılar bu fakülte(ler)de lisansüstü eğitim yapabilmelidir. İç ve dış güvenliğe karşı önemli tehditlerin bulunduğu ülkemizde böylesine önemli bir alanda sivil bir güvenlik bilimleri fakültesinin bulunmaması önemli bir eksiklik olarak değerlendirilmektedir.

$>$ Her bir meslek kolunun o mesleğe yönelik etik ilkeleri vardır. "özel güvenlik görevlileri meslek etik ilkeleri" mensupları tarafından belirlenmelidir. Özel güvenlik temel eğitimi veren kuruluşlarda ve özel güvenlik görevlisi yetiştiren üniversitelerin ilgili programlarında "özel güvenlik görevlileri meslek etik ilkeleri” başlığını taşıyan bir ders bulunmalıdır.

> Kamusal hizmet üreten özel güvenlik sektörü dernek örgütlenmesinden çıkarak “Özel Güvenlik Meslek Odaları Birliği”" statüsünde kamu kurumu niteliğindeki bir meslek kuruluşu olarak örgütlenmelidir. Kanunla kurulması gereken bahse konu “Özel Güvenlik Meslek Odaları Birliği” barolar, eczacılar, mühendisler odaları gibi çalışanların hakkını ve hukukunu korumalı, mesleğe giriş ve çıkışlar meslek odası tarafından takip edilmelidir.

> 5188 sayılı Özel Güvenlik Hizmetlerine Dair Kanun tekrar ele alınmalıdır. Zamanın ve sektörün gerçeklerine göre yeniden düzenlenmelidir. 
> Özel güvenlik olgusu, yönetim bilimciler özellikle güvenlik bilimleri alanında kafa yoran araştırmacılar tarafından daha fazla çalışılmalıdır.

KAAN projesi bitmeyen bir yolculuğun adı olmalıdır. Proje sürdürülebilir olmalı daha fazla yaygınlaştırılmalıdır. Proje uluslararası boyuta taşınmalıdır. Projenin geleceği ve yaygınlaştırılması için Avrupa Güvenlik Hizmetleri Konfederasyonunu (Confederation of European Security Services - CoESS) projeden haberdar etmek ve CoESS'in WEB sayfasında projeye yer verilmesini sağlamak oldukça önemlidir. 


\title{
EXTENDED ABSTRACT
}

\section{A Research on KAAN project and Job Satisfaction of Private Security Officers: An Empirical Study}

\author{
Hakan İnankul \\ Turkish National Police, Private Security Supervision Department
}

One of the most important functions of the state is to ensure that people live in safety and order, away from any threat and danger. The state carries out this function through the police, gendarmerie and coast guard organizations, which are defined as general law enforcement in the field of internal security, that is, by the public administration, which is the executive tool of the state.

After different social, cultural and economic developments, states have partially withdrawn from the security of individuals and private areas opened to the public, paving the way for the emergence of the private security phenomenon and sector. In other words, states have allowed the emergence of a huge security industry in which tens of thousands of people work and thousands of private security companies and educational institutions have emerged by creating the legal infrastructure for the provision of security services, which is their primary duty, to be seen by private persons, albeit partially, provided that they remain under their supervision and control.

The State is the owner, controller, regulator and chief supplier of the security phenomenon in our country. State internal security services are carried out by the Turkish National Police (TNP) under the Ministry of Interior, the Gendarmerie General Command and the Coast Guard Command. The majority of companies, educational institutions and employees in the private security industry are under the responsibility of TNP.

The task of supervising, regulating and conducting training-examination activities in the private security sector on behalf of the Ministry of Internal Affairs is carried out by the TNP Private Security Inspection Department (PSID) within the framework of the relevant legislation. Another aim of the PSID is to ensure the integration of the general law enforcement with private security and to make efforts to include private security services more in the 
total quality of internal security of the country. In order to achieve this goal, the General Law Enforcement - Private Security Cooperation and Integration (KAAN) Project - which was prepared and implemented by the Directorate of Private Security Inspection, was put into operation primarily on 25 March 2019 in the province of Istanbul and then in other provinces.

Private security guards, whose number exceeds 300 thousand, have the authority to search, seize, and use weapons and force when the conditions are met. Private security guards who have important powers that directly concern human rights and freedoms and human life; Factors such as the basic and in-service training they receive, the value and respect they receive in the workplace, their job security, working conditions, the wages they receive are sufficient to support their lives, namely their job satisfaction. There is no doubt that a private security guard who is not satisfied with his job can not be expected to provide a quality security service or to be happy at work and in private life.

The aim of the study is to disseminate the KAAN project, to promote the project nationally and internationally through this publication, to roughly examine the emergence of the private security industry and to measure the job satisfaction of private security guards. In addition, to produce solutions to problems that negatively affect the job satisfaction of private security guards (if any). As a method for this, a field study based on questionnaire was conducted besides the examination of the scientific activities that stand out in the literature. It is possible to talk about the potential of the findings, especially in the conclusion and evaluation part of the study, to contribute to the private security sector, literature and security policy makers, on which very few academic studies have been conducted in the country.

The emergence of private security services in today's sense in our country and in the world is a product of neo-liberal movements. States have allowed the emergence of a huge security industry in which hundreds of thousands of people work and thousands of private security companies and educational institutions have emerged by establishing the legal infrastructure for the provision of security services (provided that they remain under its control and regulation), albeit partially, by private persons. This situation is just like the state paving the way for some public services such as education and health, 
which are among the main duties of the state, to be provided by private administrations (private schools, private hospitals, etc.), provided that they remain under the control and regulatory authority.

In order to prevent crime (proactively) and fight criminals more effectively (reactive), each state wants to include the material and human resources of the private security sector in the total quality of internal security, as well as the ability of the general police. In this sense, the KAAN project is important. Because the KAAN project; Three hundred thousand private security personnel (PSG) who have received security training, who can look at the developments around them as security guards, who are scattered in all areas of life (shopping malls, subway stations, terminals, airports, hospitals, schools, parks, museums, etc.) and who can use security devices and technologies, It aims to use more effectively and efficiently in the fight. Increasing the private security sector's involvement in internal security services costs the government nothing.

Within the scope of the project, effective communication tools are used between the general law enforcement and private security. When PSGs encounter a crime or a suspicion of crime, they inform the general law enforcement immediately with predefined communication tools. Thanks to the instantaneous flow of information for each subject, which is named as KAAN notification, the general law enforcement can intervene in-possible- incident (s) within minutes. Each KAAN notification is recorded by provincial police directorates. Thanks to these records classified and detailed according to crimes, the contribution of this project to internal security management can be demonstrated statistically in the future.

The researcher is aware of the working conditions, personal rights, workload, etc. has heard complaints about. However, after this field study, it was revealed that the job satisfaction of PSGs was higher than expected. $90 \%$ of PSGs participating in the study stated that they are satisfied / partially satisfied with working as PSG. One of the striking results of the study is that all women in particular are satisfied with working as PSG.

It is considered that making the following administrative and legal regulations regarding the improvement and development of the private security sector, which contributes significantly to the internal security management of the country, will contribute to the field: 
- When the Web pages of the universities with Private Security Programs are examined, it is seen that each university teaches / teaches their own courses. The courses and their contents should be determined by working with the Police Academy Presidency, Gendarmerie and Coast Guard Academy and Private Security Inspection Presidency of the universities where private security programs are available. Courses with the same curriculum should be taught in the private security program of each university. In addition, faculty members and staff who teach in private security programs should be composed of instructors who work in the field of security science and, if possible, come from the field. Instead of preparing individual lessons, lessons should be prepared in accordance with the reality of the private security sector and these lessons should be given by experts.

- Private security personnel should specialize according to the field they work, as in the whole world. For some private security services, the obligation to receive specialization training in the relevant field should be introduced with a new regulation. Private security training institutions should have the capacity to provide specialist training on issues such as close protection, strategic building and facilities protection, airport security, money and valuable goods transportation.

- Faculty of Security Sciences should be opened in at least one civil university. This faculty should give the graduates of the universities 'Property Protection and Security Program' the opportunity to complete a license. In addition, police officers, soldiers and researchers wishing to specialize in security should be able to do postgraduate education in these faculty (s). The absence of a civil security science faculty in such an important area in our country, where there are significant threats to internal and external security, is considered to be an important deficiency.

- Each profession has ethical principles for that profession. "PSG's should be determined by the members of the professional ethical principles". There should be a course titled "professional ethical principles of private security guards" in institutions that provide basic private security training and in relevant programs of universities that train private security guards. 
- The private security sector, which produces public services, should not be organized as an association and should be organized as a public institution in the status of "Union of Private Security Professional Chambers". The "Union of Private Security Professional Chambers", which should be established by law, should protect the rights and laws of employees such as bar associations, pharmacists, chambers of engineers, entry and exit to the profession should be followed by the trade association.

- Law No. 5188 on Private Security Services should be reconsidered. It should be rearranged according to the realities of the time and the industry.

- The private security phenomenon should be further studied by management scientists, especially researchers who have thought about security sciences.

- KAAN project should be the name of an endless journey. The project should be sustainable and expanded more. The project should be moved to an international dimension. For the future and dissemination of the project, it is very important to inform the Confederation of European Security Services (CoESS) about the project and to include the project on the website of CoESS.

\section{Kaynakça / References}

Ağır, B.S. (2011). Güvenlik kavramını yeniden düşünmek: Küreselleşme, kimlik ve değişen güvenlik anlayışı. Güvenlik Stratejileri, 22, 97-131.

Aşkın, H. (2019). Bölücü terörle mücadele ve toplumsal duyarlhlık oluşturmada sosyal medya faktörü: İzmir Polisi üzerine bir araştrma. Doktora Tezi,Gazi Üniversitesi Sosyal Bilimler Enstitüsü, 02.08.2020 tarihinde (https://tez.yok.gov.tr/UlusalTezMerkezi/tezSorguSonucYeni.jsp adresinden erişilmiştir.

Boztepe, M. (2018). Yeni kamu yönetimi anlayışı ve geleneksel kamu personel rejimi üzerine etkileri. Afyon Kocatepe Üniversitesi Sosyal Bilimler Dergisi, 20(3), 191-210.

Carlos Montero Bagatella, J. (2013). El concepto de seguridad en el nuevo paradigma de la normatividad mexicana, Región y sociedad, xxv(58), 203238.

Durdu, Z. (2009). Modern devletin dönüşümünde bir ara dönem: Sosyal refah devleti. Muğla Üniversitesi Sosyal Bilimler Enstitüsü Dergisi, 22, 37-50. 
EGM. (2020). KAAN. $01.08 .2020 \quad$ tarihinde https://www.egm.gov.tr/ozelguvenlik/kaan adresinden erişilmiştir. Eryılmaz, B. (2016). Kamu yönetimi. Umuttepe Yayınları, İstanbul. Eser, B., Memişoğlu, D. ve Özdamar, G. (2011). Sosyal siyasetin üretilmesi sürecinde refah devletinden neo-liberal devlete geçiş: Devletin kamu hizmeti sunma işlevinin değişimi. Süleyman Demirel Üniversitesi İktisadi ve İdari Bilimler Fakültesi Dergisi, 16(2), 201-217.

Günter Brauch, H. (2008). Güvenliğin yeniden kavramsallaştırılması: Barış, güvenlik, kalkınma ve çevre kavramsal dörtlüsü. Uluslararası İlişkiler, 5(18), 1-47.

İnal, K. (2014). Sürücü eğitiminde informal öğrenmenin rolü: Türkiye örneği. Mediterranean Journal of Humanities 4(1), 181-189.

Krahmann, E ve Friesendorf, C. (2011). The role of private security companies (PSCS) In Csdp missions and operations, directorate: General for external policies of the union. tarihinde file://C:/Users/HP/Downloads/KrahmannFriesendorfEUStudy2011.pdf adresinden erişilmiştir.

Özalp, H. (2016). Özel güvenlik risk yönetim sistemi. İzmir, Birleşik Matbaacıllk.

Sancak, K. (2013). Güvenlik kavramı etrafındaki tartışmalar ve uluslararası güvenliğin dönüşümü. Sosyal Bilimler Dergisi, 6, 123-134.

Serper, Ö ve Aytaç, M. (2000). Örnekleme. Bursa: Ezgi Kitabevi, 2. Baskı.

Zedner, L. (2009). Güvenlik. (O. Defne, Çev.), İstanbul:Acar Basım ve Cilt San. Tic. A.Ş. 2015.

\section{Kaynakça Bilgisi / Citation Information}

İnankul, H. (2020). KAAN Projesi ve özel güvenlik görevlilerinin iş memnuniyeti üzerine bir araştırma:Ampirik bir çalışma. OPUS-Uluslararası Toplum Araştırmaları Dergisi, 16(32), 4987-5014. DOI: 10.26466/opus.779809 